\title{
Diagnostic Study of Ginger Market Access for Eastern and Western region of Nepal
}

\author{
Arun GC ${ }^{1 a^{*}}$, Sirish Pun ${ }^{2 b}$, Sudip Devkota ${ }^{3 c}$, Kiran Ghimire ${ }^{4 d}$ \\ ${ }^{I}$ Agriculture Extension Officer, Ministry of Agriculture, Land Management and Cooperatives, Kathmandu, Nepal \\ ${ }^{2}$ Senior Agriculture Economist, Ministry of Agriculture, Land Management and Cooperatives, Kathmandu, Nepal \\ ${ }^{3}$ Agriculture Officer, Ministry of Agriculture, Land Management and Cooperatives, Kathmandu, Nepal \\ ${ }^{4}$ Plant Protection Officer, National Plant Quarantine Program, Kathmandu, Nepal
}

*Corresponding author

A R T I C L E I N F O

Research Article

Received : 28/07/2018

Accepted : 26/01/2019

\author{
Keywords: \\ Ginger \\ Trade \\ Market access \\ Nepal \\ Diagnostic Study
}

A B S T R A C T

Ginger (Zingiber officinale) is one of the important spices in the world. Nepal is the fourth largest producers of ginger in the world, which produced 271.863 MT in 2016. In Nepal, seventy districts are producing ginger and around 400.000 households are involving in the ginger farming which is the chief source of the household income. Moreover, ginger has prioritized by several policies and strategies of the Government of Nepal. This paper examined the production trend and market access of Nepali ginger considering the ginger global market. A diagnostic study of production, value addition, and the marketing system was carried out between the eastern and the western part of Nepal. The secondary information was reviewed and analysed for the study. Likewise, the key informant survey was performed for the primary data and information. For Nepali ginger, India is found constantly top destination. The result of price index suggested that Nepali ginger is losing significant potential earning by not having top most lucrative markets for fresh ginger. Moreover, the trend of the export is ever fluctuating and the result showed that trade of ginger to India in term of export is more stable from the western region as compared to the eastern region. The study found that the major determinants of ginger market access are quality of ginger produced, value addition, level of trade facilitation, and domestic production and the import of India from other countries.

gcarun88@gmail.com sudip.iaas@gmail.com (i) https://orcid.org/0000-0002-2548-5177 b@dilson064@gmail.com
(i) https://orcid.org/0000-0002-7813-010X d@kiran.ghimire17@gmail.com

(iD) https://orcid.org/0000-0003-2568-6742 (iD) https://orcid.org/0000-0002-2411-7233

\section{Introduction}

Ginger (Zingiber officinale) is the underground rhizome and the important spice and medicinal crop in the world (Vasala, 2012; Madan, 2005; Poudel et al., 2015). Globally, both the import and export value of ginger is growing every year (USAID, 2011). It is a major exportable agricultural commodity of Nepal (Samarth, 2014; Eze and Agbo, 2011), where agriculture is the important economic activity (GC and Ghimire, 2018). The different form of ginger like fresh ginger, dried ginger (Sutho), powder etc. are being exported from Nepal. India is the main export destinations (GC, 2019) for Nepalese ginger and accounts for close to $94 \%$ of fresh ginger export and $6 \%$ of processed ginger (Samarth, 2014). Mostly, Sutho is prepared in the western part of Nepal (Khanal, 2018), however, it is rare in the eastern part (HVAP, 2011). Amount of ginger produced is higher in the eastern region of Nepal as compared to the western region. Among the other agricultural commodities, it has top most exportable value (Poudel et al., 2015).

Nepal Trade Integration Strategy (NTIS) 2016 has prioritized ginger, considering its strength induced by favorable geo-climatic condition and its high quality, and acknowledging increasing demand in the global market (MoC, 2016). It is especially major source of income in in mid hill and high hill (Khanal, 2018). It has also placed at priority by the previous edition of the NTIS (2010) (MoCS, 2010). An estimated 400.000 household grow ginger in Nepal and is self-sufficient in ginger, which the country is available for just a few agricultural commodities.

In $2017 / 18$, the total area under ginger cultivation was 22,649 hectares (ha) and the total production was 279,504 MT with 12.34 MT/ha productivity (MoAD, 2018). There are two types of ginger produced in Nepal: Nase - the fibrerich variety and Bose- the low-fibre rhizome. In 2017/18, over 10,645 MT of fresh and 826 MT of crushed or ground ginger having worth of Rs 408 Million was exported to India (TEPC, 2018). On an average $85 \%$ of the total production is estimated to be marketed by the producers, either as fresh rhizome or as a mother rhizome. The producers retain $30-35 \%$ of the total production for seed purpose but later a part of this stock again enters the market (CADP, 2008). Among market surplus, about $75 \%$ ginger 
is traded as fresh and remaining $25 \%$ as processed. Dried ginger (Sutho) is the major processed product of Nepal and farmers are making it in their own traditional way. Other value-added products are candy, powder, squash, pickles (FAO, 2002), however, their production share is nominal.

Ilam, Birtamod, Dharan, Biratnagar, Birgunj, Hetauda, Butwal, Bhairahawa, Tulsipur, Nepalgunj, Dhangadhi, Mahendranagar and Kathmandu are the major market hubs for ginger in Nepal (HVAP, 2011). The major Indian markets for the ginger from eastern region of the country are Siliguri and Kolkata passes via Naxalbari. Whereas, ginger from the mid-western and the far-western region mainly goes to Gorakhpur, Lucknow, Kanpur, Bareli and Banarash of India. Some quantity of ginger is also exported to Delhi, Jaipur and Amritsar markets (HVAP, 2011). Despite being the largest importer of Nepalese ginger, India is creating issues in the export of Nepalese ginger to India (Poudel et al., 2015) imposing import ban time and again, specifically when they have their own enough production. They have repeatedly obstructed the import in the peak season, causing up to the complete loss of product. (Republica Daily, 2018). So, Nepali traders are facing difficulties to export ginger to India (Kantipur Daily, 2017). Obstruction of ginger export is more prevalent in the eastern region as compared to the western part of Nepal. To diagnose the differential regional trade situation of ginger in the eastern and the western part of Nepal, an intensive study was realized. Therefore, the general objective of this study was to identify the problems in the ginger trade and to suggest the appropriate solutions for the problem, considering the global ginger market.

\section{Methodology}

The primary and the secondary data and information were used and both qualitative and quantitative analysis ware carried out for this study. For the study purpose, to compare the market access of Nepali ginger, the country is divided into two parts - the western and the eastern part. Total six customs points- three from each region, significant ginger trade is which significant ginger trade is occurring, were considered for this study, three from each region, were considered for this study.

For the primary data, key informant survey (KIS) was performed. A checklist was prepared for the key informant survey and the survey was executed by an individual meeting and by a telephone conversation. The exhaustive list of key informants was obtained from the AgroEnterprise Center - an umbrella organization of agriculture entrepreneurs in Nepal, and the Nepal Ginger Producers and Traders Association (NGPTS). The key informants were selected purposively from the exhaustive list upon recommendation from the AEC and NGPTA.

For the secondary data, the production data were accessed from the statistical information of the Ministry of Agriculture and Livestock Development. Likewise, export data were accessed from the databank of Trade and Export Promotion Center and for the global trade data, a databank of the International Trade Center (ITC) was accessed. The data from FAO databank was also used for the study and for triangulation. Similarly, a rigorous desk review was performed using published pre-reviewed and other articles, and reports. Production, export quantity and price data were compiled, processed and presented. Thus obtained secondary data were tabulated and compared.

The global trade data of ginger has been used under the Harmonized System of Coding (HS) as developed and promoted by the World Customs Organization and is presented in Table 1.

For the better comparison, per unit price and the price index was calculated. The price index is defined as the ratio of price for " $x$ " country and the maximum price prevailed during this period. The price index can be used as the opportunity cost of the ginger.

$$
\mathrm{P}_{\mathrm{i}}=\mathrm{P}_{\mathrm{x}} / \mathrm{P}_{\max }
$$

Where,

$\mathrm{P}_{\mathrm{i}} \quad$ : Price index

$\mathrm{P}_{\max }$ : Maximum per unit import price prevailing in the global market

$P_{x} \quad$ : Per unit import price of country " $\mathrm{x}$ ".

Table 1 Description of HS Code

\begin{tabular}{c|ll}
\hline SN & \multicolumn{1}{|c}{ HS Code } & Description \\
\hline 1 & 091010 & Ginger \\
2 & 091011 & Dried Ginger \\
3 & 091012 & Grounded Ginger \\
4 & 09101010 & Ginger: Fresh \\
5 & 09101020 & Ginger: Dried, unbleached \\
6 & 09101030 & Ginger: Dried, bleached \\
7 & 09101040 & Ginger: Powder \\
8 & 09101090 & Ginger: Other \\
9 & 091011 & Ginger, neither crushed nor ground \\
10 & 09101110 & Ginger, neither crushed nor ground + detail not available \\
11 & 09101120 & Ginger, neither crushed nor ground + detail not available \\
12 & 09101130 & Ginger, neither crushed nor ground + detail not available \\
13 & 09101190 & Ginger, neither crushed nor ground + detail not available \\
14 & 091012 & Ginger, crushed or ground \\
15 & 09101210 & Ginger, crushed or ground + detail not available \\
16 & 09101290 & Ginger, crushed or ground + detail not available \\
\hline
\end{tabular}




\section{Result and Discussion}

\section{Ginger Global Market}

To study the global market of ginger, we used data from trade databank of International Trade Center (ITC). According to the ICT, ginger has been traded under three HS codes - 091010, 091011 and 091012. However, India is importing ginger under more HS codes - 09101010, 09101020, 09101030, 09101040, 09101090, 091011, 09101110, 09101120, 09101130, 09101190, 091012, 09101210 and 09101290. Moreover, Nepal is found exporting ginger under HS codes - 09101000, 09101110, 09101190, and 09101200. The extension of HS code from six digit to eight digit is the national interpretation and categorization of HS code.

Based on the ITC data (ITC, 2018), between 2001 and 2017, the top ten importers of ginger by the quantity and by value under HS code 091010 are presented in the following Table 2 .

Japan is the top destination of ginger in terms of value and quantity. India is at third by quantity but at eight by value, which signifies that the per unit price of ginger under HS 091010 is not so attractive as compared with other markets. The price index will position the market regarding the attractiveness of the market, which will be discussed later. However, a market should not be prioritized by price index alone; it should be tied up with total quantity also.

Likewise, under HS code 091011; the top 10 importers by the quantity and by value during 2001 and 2017 are presented in Table 3 . The figures revealed that ginger under HS 091011, again Japan has secured the top position followed by the United State. India is at $10^{\text {th }}$ position by quantity imported; however, it is not in the list by value, rather Bangladesh is at $5^{\text {th }}$ by volume and $7^{\text {th }}$ by value. Pakistan is at $3^{\text {rd }}$ by volume and $4^{\text {th }}$ by value. It showed that South Asia is the main sink for ginger under HS 091011 and being the top producer, Nepal has a better position than other producers. It is also indicating that value-addition is possible and is profitable in Nepal. Moreover, various studies are also suggesting that value-added ginger is not facing Non Traffic Barriers (NTB), which is recurrent in fresh ginger.

Table 2 Top ten importers of Ginger (HS code 091010) by value and quantity during 2001-2017*

\begin{tabular}{c|lclc}
\hline SN & \multicolumn{1}{c}{ Country } & Value $(\$ 1000)$ & Country & Quantity (Ton) \\
\hline 1 & Japan & 991.000 & Japan & 963.053 \\
2 & United States of America & 406.973 & Pakistan & 470.874 \\
3 & Pakistan & 263.602 & India & 368.264 \\
4 & United Kingdom & 208.617 & United States of America & 326.140 \\
5 & Netherlands & 205.289 & Malaysia & 310.963 \\
6 & Malaysia & 182.930 & Bangladesh & 187.506 \\
7 & Germany & 149.943 & Saudi Arabia & 178.318 \\
8 & India & 126.559 & United Kingdom & 172.311 \\
9 & Bangladesh & 126.060 & Netherlands & 151.289 \\
10 & Canada & 93.834 & Korea, Republic of & 112.438 \\
\hline
\end{tabular}

"Source: ITC (2018)

Table 3 Top ten importers of Ginger (HS code 091011) by value and quantity during 2001-2017*

\begin{tabular}{c|lclc}
\hline SN & \multicolumn{1}{c}{ Country } & Quantity (Ton) & Country & Value (\$1000) \\
\hline 1 & Japan & 369.029 & Japan & 570.025 \\
2 & United States of America & 358.981 & United States of America & 545.281 \\
3 & Pakistan & 345.446 & Netherlands & 389.371 \\
4 & Netherlands & 254.473 & Pakistan & 228.541 \\
5 & Bangladesh & 247.045 & Germany & 183.779 \\
6 & United Arab Emirates & 173.628 & United Kingdom & 169.960 \\
7 & Saudi Arabia & 158.279 & Bangladesh & 167.163 \\
8 & Malaysia & 150.796 & Saudi Arabia & 149.905 \\
9 & United Kingdom & 118.710 & Russian Federation & 134.020 \\
10 & India & 116.424 & Malaysia & 127.457 \\
\hline
\end{tabular}

"Source: ITC (2018)

Likewise, under HS code 091012, the top 10 importers by the quantity and by value during 2001 and 2017 are presented in Table 4. Japan, the top destination of ginger under HS code 091010 and 091011 , is at $2^{\text {nd }}$ and for the HS code 091012, Malaysia secured the top position by volume and Germany by value. More importantly, none of the South Asian countries is at top 10 positions under this HS code. Europe and America are dominating under this category of ginger. However, the total volume of ginger under this HS is fewer than previous categories. Nevertheless, by value, this is the most expansive, which will be discussed under per unit price chapter later.

Note that the ITC databank showed there are no data after 2012 under HS code 091010 and there are no data before 2012 under HS code 091011 and 091012 due to change in HS coding system in 2012. Moreover, the import data is difficult to disintegrate as fresh and dried, and the issue of re-exportation is always there (Plotto, 2002).

\section{Per Unit Price and Price Index}

Along with the total import quantity, per unit price is an important parameter for trade. The data were accessed from ITC databank between 2001 and 2017 to study per Metric Ton (Mt) price and price index of ginger. Per unit price and price index enable to prioritize the potential market. If the market has higher the price index and is importing at significant quantity, the exporter must prioritize the market.

For the HS code 091010, Germany showed the best export destination. However, Germany is not the top ten 
importer of ginger under this HS code. Japan is the top importer of ginger under this HS code, but the price index of Japan is just 0.39 as presented in Figure 1. Likewise, the price index of India, which is the major export destination of Nepal under this HS code, is just 0.13. It means Nepali ginger is losing its $87 \%$ of potential value. Bangladesh exhibited as a better sink for Nepali ginger under this HS code than India. Price Index of Bangladesh under this HS code is 0.25 , which means exporting ginger to Bangladesh instead of India will generate $12 \%$ more value.

Per ton import price of Germany was found the top (USD 2.660) followed by Netherland, USA and UK. The detail of per unit price is presented in Table 5.

For the HS code 091011, Russian Federation was found the most attractive market followed by Germany, Japan, Netherlands and the USA. The price index of India is just 0.22 as presented in Figure 2, which means exporting to India is losing $78 \%$ of potential value. Contrary to previous HS code, Bangladesh was not found significantly attractive than India, although it is better under this HS code. Nevertheless, switching market destination from India to Bangladesh would not a wiser decision from the price perspective. Again, under this HS code, Europe and America have demonstrated as the most lucrative market including Japan.

Per ton price of ginger under HS code was found USD 2,750 in Russian Federation and was found USD 600 in India. Detail per unit price has been presented in Table 6.

Table 4 Top ten importers of Ginger (HS code 091012) by value and quantity during 2001-2017*

\begin{tabular}{c|lclc}
\hline SN & \multicolumn{1}{c}{ Country } & Value $(\$ 1000)$ & Country & Quantity (Ton) \\
\hline 1 & Germany & 83.686 & Malaysia & 46.270 \\
2 & Japan & 80.527 & Japan & 27.072 \\
3 & United States of America & 44.588 & Germany & 24.777 \\
4 & United Kingdom & 38.496 & United States of America & 14.324 \\
5 & Malaysia & 37.205 & United Kingdom & 10.022 \\
6 & Netherlands & 21.766 & Netherlands & 6.569 \\
7 & France & 12.774 & Oman & 3.869 \\
8 & Canada & 11.158 & Australia & 3.054 \\
9 & Australia & 8.241 & France & 2.958 \\
10 & Poland & 7.293 & Italy & 2.891 \\
\hline
\end{tabular}

*Source: ITC

Table 5 Per ton price of ginger (HS 091010)

\begin{tabular}{l|c}
\hline \multicolumn{1}{c|}{ Country } & Per ton price \\
\hline Germany & 2.66 \\
Netherlands & 1.36 \\
USA & 1.25 \\
UK & 1.21 \\
Morocco & 1.13 \\
Canada & 1.10 \\
Japan & 1.03 \\
Singapore & 0.90 \\
Bangladesh & 0.67 \\
Malaysia & 0.59 \\
Pakistan & 0.56 \\
Saudi Arabia & 0.53 \\
UAE & 0.49 \\
Korea, Republic of & 0.38 \\
India & 0.34 \\
\hline
\end{tabular}

Table 6 Per ton price of ginger (HS 091011)

\begin{tabular}{l|c}
\hline \multicolumn{1}{c|}{ Country } & Per ton price \\
\hline Russian Federation & 2.75 \\
Germany & 2.61 \\
Japan & 1.54 \\
Netherlands & 1.53 \\
United States of America & 1.52 \\
Canada & 1.48 \\
United Kingdom & 1.43 \\
Singapore & 1.13 \\
Saudi Arabia & 0.95 \\
Malaysia & 0.85 \\
Korea, Republic of & 0.71 \\
Bangladesh & 0.68 \\
Pakistan & 0.66 \\
India & 0.60 \\
United Arab Emirates & 0.59 \\
\hline
\end{tabular}

Price Index of Ginger (HS 091010)

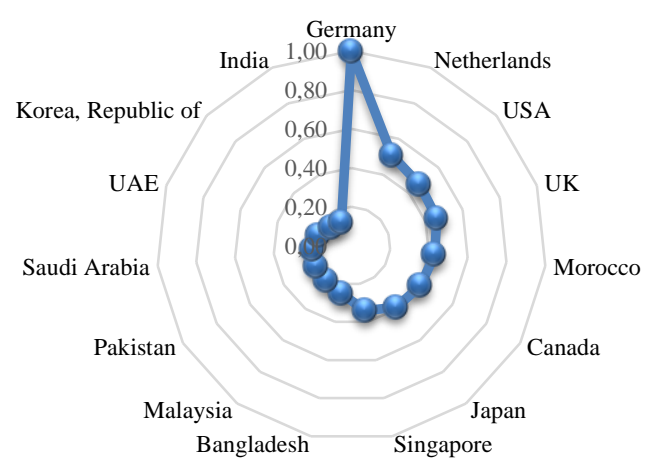

Figure 1 Price index of ginger (HS 091010)

Price Index of Ginger (HS 091011)

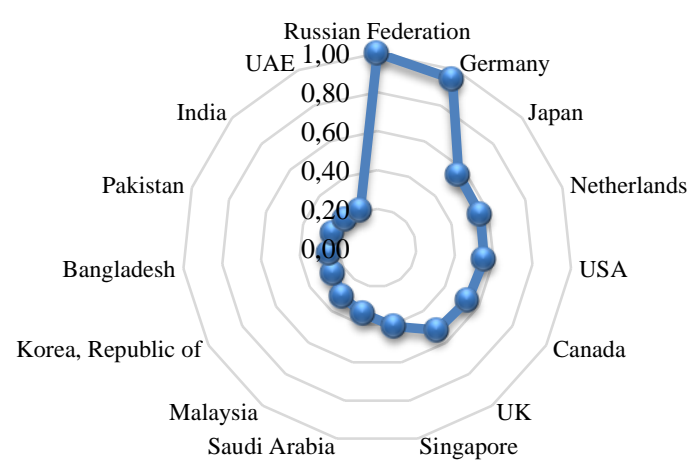

Figure 2 Price index of ginger (HS 091011) 
For the HS code 091012, France was found the most attractive market. Despite continuous lower price index of India in previous HS codes, India has better price index (0.88) under HS code 091012 as presented in Figure 3. It clearly indicates that if Nepal can export ginger under HS code 091012, Indian market itself is a better option. Next best alternative for Nepali ginger under this HS code are France, Canada and the UK.

Per ton price of ginger under HS code 091012 was found USD 4320 in France and USD 3780 in India. Other SAARC countries were not found as a good Market for ginger under HS code 091012.

\section{Indian Market}

The ITC revealed that India was importing the significant quantity of ginger under HS code 091010 till 2012, however, onward, the import was nil, this could have happened due to change in the HS code. During this period, Nepal is consistently the top exporter of the ginger and importantly, per ton price was the lowest among the top exporters except in 2008 when Myanmar's per ton price was USD 210 and Nepal's per ton price was USD 220.

Table 8 presents the import trend of India under HS 091010 during 2008 and 2012, and Table 9 presents about the per ton price of imported ginger in India during the same period.

The market access information of the ITC showed that India's average MFN tariff for the agricultural product is around $40 \%$ as presented in Figure 4. However, according to the Article IV of the Treaty of Trade between the Government of Nepal and the Government of India states that basic customs duty and quantitative restrictions on primary products are exempted and the protocol to the Treaty of Trade (IV) further clarify the provision (Anonymous, 2010). Therefore, the tariff rate of India positively affects the competitiveness of Nepali ginger in the Indian market.

Table 7 Per Ton Price of Ginger (HS 091012)

\begin{tabular}{l|c}
\hline \multicolumn{1}{c|}{ Country } & Per ton price \\
\hline France & 4.32 \\
Canada & 4.18 \\
United Kingdom & 3.84 \\
India & 3.78 \\
Germany & 3.38 \\
Netherlands & 3.31 \\
USA & 3.11 \\
Japan & 2.97 \\
Australia & 2.70 \\
South Africa & 2.63 \\
Belgium & 2.62 \\
Italy & 2.45 \\
Korea, Republic of & 1.09 \\
Malaysia & 0.80 \\
Oman & 0.39 \\
\hline
\end{tabular}

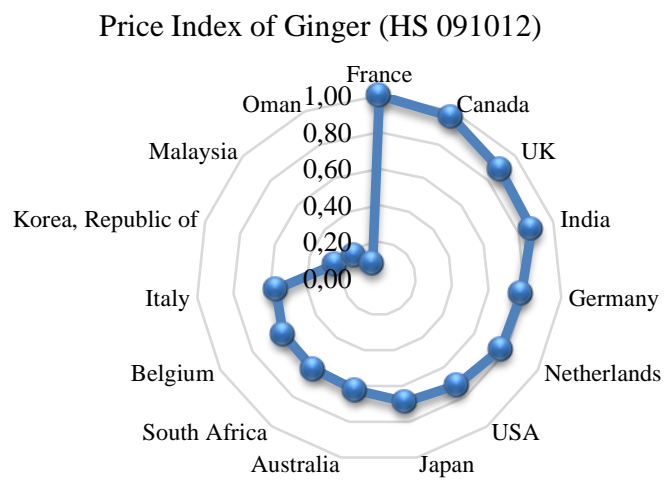

Table 8 India's import of ginger (HS 091010) during 2008-2012 (in ton)

\begin{tabular}{l|rrrrrr}
\hline \multicolumn{1}{c}{ Exporters } & 2008 & 2009 & 2010 & 2011 & 2012 & Total \\
\hline Nepal & 36.917 & 37.244 & 24.331 & 21.284 & 46.533 & 166.309 \\
Nigeria & 2.852 & 1.591 & 2.493 & 1.583 & 1.636 & 10.155 \\
Ethiopia & 2.548 & 2.100 & 1.591 & 275 & 65 & 6.579 \\
China & 2.592 & 925 & 1.384 & 315 & 149 & 5.365 \\
Myanmar & 377 & 263 & 870 & 332 & 237 & 2.079 \\
Indonesia & - & - & - & 133 & 22 & 155 \\
\hline
\end{tabular}

Table 9 India's per ton import price of ginger (HS 091010) during 2008-2012 (Thousand USD/ ton)

\begin{tabular}{l|ccccc}
\hline \multicolumn{1}{c}{ Exporters } & 2008 & 2009 & 2010 & 2011 & 2012 \\
\hline Nepal & 0.22 & 0.20 & 0.26 & 0.28 & 0.23 \\
Nigeria & 0.90 & 0.87 & 1.86 & 2.89 & 1.69 \\
Ethiopia & 0.72 & 0.72 & 1.43 & 3.21 & 1.57 \\
China & 1.30 & 1.19 & 1.65 & 4.14 & 2.83 \\
Myanmar & 0.21 & 0.27 & 2.00 & 2.29 & 1.46 \\
Indonesia & NA & NA & NA & 3.24 & 2.23 \\
\hline
\end{tabular}

\section{Indian SPS Requirement}

According to the Plant Quarantine Order, 2003 (Anonymous, 2003), only Nepal is allowed to export ginger (Zingiber spp) for consumption. However, it has allowed rhizome for propagation from Australia, Bhutan, China, Fiji, Mauritius, Nigeria, Suriname, Nepal and Thailand, subject to some criteria. Ginger can be exported in the two forms from Nepal:

Rhizome for consumption: For the consumption purpose, there is no need of additional Declaration to be incorporated into Phytosanitary Certificate. But the consignment should be free from quarantine weed seeds and soil.

Rhizome for propagation: For the multiplication purpose, there is no need of additional Declaration to be incorporated into Phytosanitary Certificate. But the consignment should be free from soil and post-entry quarantine for 2-3 months except for research purposes. 


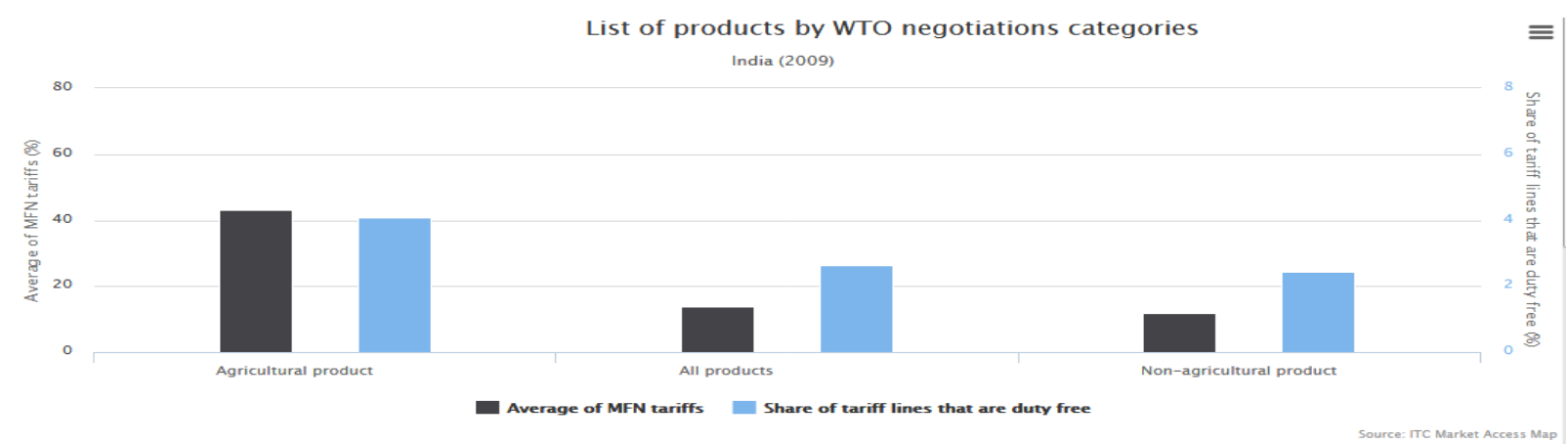

Figure 4 List of products by WTO negotiations categories of India (2009)

Production trend of Ginger (MT)

\begin{tabular}{|c|c|c|c|c|c|c|c|c|}
\hline \multirow{4}{*}{$\begin{array}{r}120000 \\
100000 \\
80000 \\
60000 \\
40000 \\
20000\end{array}$} & & & \\
\hline & & & & & & & & \\
\hline & & & & & & & & \\
\hline & & & & & & & & \\
\hline U & 2008 & 2009 & 2010 & 2011 & 2012 & 2013 & 2014 & 2015 \\
\hline EDR & 51956 & 55259 & 77556 & 79361 & 99643 & 83488 & 103627 & 92342,62 \\
\hline CDR & 24791 & 23752 & 22946 & 25253 & 27833 & 29652 & 37414 & 38416,94 \\
\hline -WDR & 48415 & 48777 & 54736 & 55355 & 67364 & 59780 & 75176 & 62574,8 \\
\hline MWDR & 21865 & 30519 & 35516 & 38385,4 & 39724,4 & 36826 & 31768,1 & 24347,51 \\
\hline FWDR & 14124 & 20622 & 20037 & 17935 & 20644 & 25287 & 28168 & 24865 \\
\hline
\end{tabular}

Figure 5 Production trend of ginger in Nepal by development region during 2008-2015

\section{Production and Trade of Ginger in Nepal}

Nepal is growing ginger in 22,649 ha with the production of $271,863 \mathrm{Mt}$ and productivity of $12.34 \mathrm{Mt} / \mathrm{ha}$; among them, more than $50 \%$ coverage and almost equal share in production came from top 10 ginger producing districts in 2017(MoAD, 2018). Similarly, more than 75\% of area and production is coming from the top 20 districts in 2017. The national average productivity of ginger was 12.34 T/ha in 2017(MoAD, 2018).

Ginger production trend from 2008 to 2015 is presented in Figure 5, which showed that among five-development regions, contribution of ginger production by volume is always higher at eastern development region followed by western development region whereas minimum production was observed in far western development region except for the year of 2015. While analyzing the production trend of 2015 , Highest (38\%) production was obtained from eastern development region (EDR) followed by western development region (WDR) (26\%), and Central development region (10\%), whereas, the least production was observed in the Mid-western development region $(9.5 \%)$ as compared with total national production.

The trend of the value of ginger export from selected customs points from 2009 to 2017 is presented in Figure 6, which revealed that both regions - eastern and western, had experienced fluctuation over the time. However, the fluctuation from the western region is less intense than the eastern region. Until 2011 the export value of ginger was declining from the western region and the trend was increasing from the eastern region. However, the following years showed increased export value from both regions. Likewise, the trend from 2014 revealed relatively stable from both regions.
From the western region, three customs points Bhairahawa, Nepalgunj and Kanchanpur were considered for the study. Among these three customs points, Bhairahawa is found to be the major export point of ginger followed by Nepalgunj and Kanchanpur. Bhairahawa also showed higher degree of fluctuation along with higher export value and Nepalgunj showed the relatively stable export in the western region.

\section{Findings from Key Informant Survey}

The finding from the key informant survey provided further insights regarding differential market access of Nepali ginger from the Eastern and the Western parts of the country.

The rhizomes produced in the eastern region are less fibrous than that of the western part. Likewise, the rhizome size of ginger from the eastern region is comparatively bigger than that of the western. Moreover, being unprocessed and bigger in size, the rhizome in the eastern side, possibility of the breakage of the rhizome is higher as compared to the western region. Ginger produced in the eastern region is more suitable for fresh consumption (table purpose), tea industry and granules or cube making. However, ginger produced in the western region are more suitable for drying, oleoresin and Sutho making.

Ginger exported the western part possess a higher degree of value addition than that of the eastern part. Moreover, drying ratio of ginger in the eastern region is reported 9:1 by weight (Fresh: Dry), whereas, it is 7:1 in the western region. As a result, the farmers from the western regions are more encouraged for drying and processing. More importantly, from the eastern region, 
Siliguri auction is not so far, which is encouraging traders to supply fresh ginger. However, in the western part, the ginger auction center is relatively far, which is compelling producers for processing.

The demand from India for Nepali ginger is ever fluctuating. Consequently, the farmers from the eastern region are highly affected, but the impact is fewer in the western region. The main reason behind the differential impact was identified as the level of value addition. In the eastern region, there is almost no value addition and farmers are forced to sell their produce whatever the price prevailed. Contrary to this, in the western region, farmers are practicing drying and processing, which is enabling them to hold ginger during unfavorable price trend. During the study period, farmers in the western region were reported to be stored ginger of current value of around 50 thousand rupees per household.

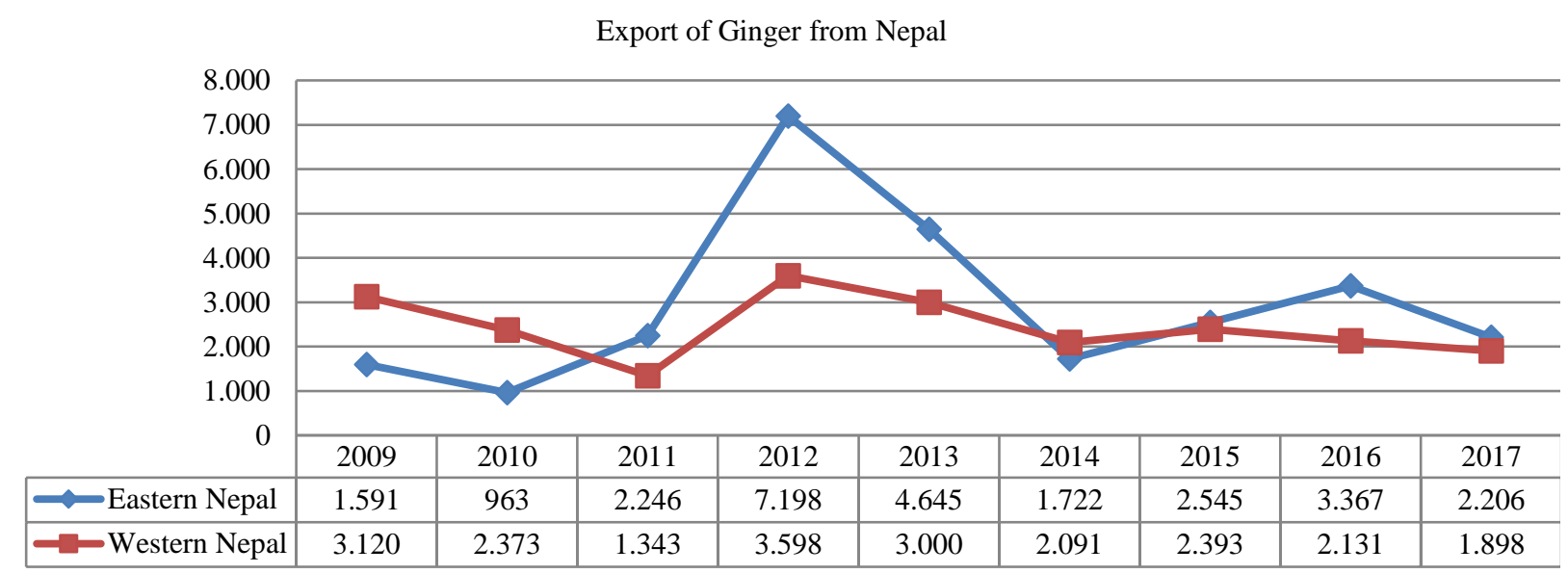

Figure 6 Total export value of ginger from selected custom points from 2009-2017

Export Value of Ginger

\begin{tabular}{|c|c|c|c|c|c|c|}
\hline $\begin{array}{l}6.000 \\
5.000\end{array}$ & & & & & & \\
\hline 4.000 & & & & & & \\
\hline 3.000 & & & & & & \\
\hline $\begin{array}{l}2.000 \\
1.000\end{array}$ & & & & $\exists$ & & \\
\hline 0 & & -5 & & & & \\
\hline & Mechi & Biratnagar & Birgunj & Bhairahawa & Nepalgunj & Kanchanpur \\
\hline$\square 2009$ & 1.324 & 0 & 267 & 1.928 & 1.080 & 112 \\
\hline$\square 2010$ & 448 & 74 & 441 & 1.716 & 657 & 0 \\
\hline$\square 2011$ & 471 & 101 & 1.674 & 804 & 409 & 130 \\
\hline$\square 2012$ & 1.417 & 340 & 5.440 & 2.863 & 651 & 85 \\
\hline$\square 2013$ & 1.195 & 266 & 3.184 & 2.173 & 645 & 182 \\
\hline$=2014$ & 1.216 & 506 & 0 & 1.574 & 436 & 81 \\
\hline$=2015$ & 1.812 & 583 & 151 & 1.927 & 466 & 0 \\
\hline$=2016$ & 1.484 & 136 & 1.746 & 1.723 & 408 & 0 \\
\hline-2017 & 2.206 & 0 & 0 & 1.433 & 464 & 0 \\
\hline
\end{tabular}

Figure 7 Export value of ginger from different custom points from 2009 to 2017

The exporters claimed that despite domestic production, India is importing a large quantity of ginger from different countries, which are competing with Nepali ginger. However, the statistics did not support the claim. The data from ITC showed that the price of the ginger from Nepal is the least among all other countries in fresh ginger. Likewise, they claimed Nigeria is the top competitor of Nepali ginger, which is supplying at USD 1.2 per kg sliced ginger against USD 4.2 per $\mathrm{kg}$ from Nepal on an average. Key informants claimed the infestation of Salmonella spp and aflatoxin in Nigerian ginger, however, it could not be verified.

The key informants claimed that Indian traders perceived that the price of Nepali ginger is highly volatile and shows a higher degree of fluctuation as compared to other countries, which is resulting some degree of hesitation among Indian traders toward Nepali ginger. However, the data from the ITC showed that Nepali ginger price is already at the lowest among the other countries.

Mainly four types of ginger are exported from Nepal: Fresh, Sliced, Powder and Sutho. Among them, the export from the eastern region is mainly as the fresh ginger and the western region exports all four types are exporting.

The exporters claimed the re-exportation of Nepali ginger to the third countries via India. However, we could not verify the fact. Nevertheless, several studies identified the possibilities of re-exportation (FAO, 2002). 
Another determinant of the ginger trade was also identified as the method of transaction. Traders are found comfortable on the transaction in the Indian currency rather than USD due to relative stability. However, due to the introduction of cash incentive by the Government of Nepal, to those traders who earn foreign currency except Indian currency has compelled traders to transact in USD (Ministry of Industries, 2013).

Ginger from Nawalparasi showed a specific case. It is acting as niche product for a specific market in Bihar state of India. As a result, they have a stable trading arrangement. Traders also confirmed the difference in illicit payment at customs points in the eastern and western regions, which is also confirmed by previous studies (HVAP, 2011). Moreover, lobbying capacity of east-based traders was found more than west-based traders. Likewise, the traders claimed that the dealing with Indian parties having industry inside Special Economic Zone (SEZ) of India is reliable and comfortable. However, we could not verify the claim.

\section{Conclusion}

Ginger is one of the important agricultural export commodities, which is the major income sources of several farming households and the major source of foreign exchange earning of the country. It is exported mainly under four forms: Fresh, Sliced, Powder and Sutho. The study was conducted to identify the differences between the eastern and the western region of Nepal in ginger trade. The eastern region is the major producer of ginger and these gingers are mostly exported in the raw (fresh) form. However, the western region exports ginger in various value-added forms along with fresh. Consequently, its export was found relatively stable. The main distinctions identified are the variety (hence quality) of ginger, processing level and export requirement including actors in importing country. Surprisingly, despite being the fourth largest producers in the world, domination of Nepali ginger in the global market is nominal and the price is exceptionally low. Moreover, ginger producers are losing a significant amount of potential value due to a lower level of processing and the higher dependency on the Indian market. Bangladesh, next to India is demonstrating as an attractive market than India. Nevertheless, Europe, America and Japan are consistently exhibiting as the most lucrative market for the ginger industry. Comparing ginger production and export pattern in the western and the eastern regions of Nepal, few vivid differences were identified. Such as market should be diverted from India to the third countries, which will be possible after value addition. The fresh ginger is posing a higher degree of risk in terms of- both price and quality. On the other hand, the processed ginger provides greater shock absorbing capacity for farmers. Moreover, it can be stored during adverse price trend. Exporting ginger to influential or relatively establish and bigger traders would also pay greater value, in case of India. Therefore, value-addition and product diversification is the foremost important for Nepali ginger industry.

\section{References}

Anonymous. 2003. Plant Quarantine (Regulation of Import into India) Order, 2003. Plant Quarantine (Regulation of Import into India) Order, 2003. Government of India.

Anonymous. 2010. Treaty of Trade, Treaty of Transit and Trade Related Agreements Between Government of Nepal and Neighbouring Countries (India, People's Republic of China and Bangladesh). Kathmandu: Nepal Trade and Warehousing Company Limited. Retrieved 2018.

CADP. 2008. Final Report, Product Chain Study Ginger. Biratnagar: MOAC, DOA, CADP.

Eze J, Agbo K. 2011. Comparative studies of sun and solar drying of peeled and unpeeled ginger. American Journal of Scientific and Industrial Research, 2(2): 136-143.

FAO. 2002. Ginger Post-harvest Operations - Post-harvest Compendium.

GC A. 2019. Nepali International Trade Before and After the World Trade Organization. InTraders International Trade Academic Journal, 77-84.

GC A, Ghimire A. 2018. SWOT Analysis of Nepalese Agricultural Policy. International Journal of Agriculture, Environment and Food Science, 2(4): 119-123. doi:10.31015/jaefs. 18020

HVAP. 2011. A Report on Value Chain Analysis of Ginger subsector in Nepal.

ITC. 2018. ITC Trade Map. Retrieved 04 03, 2018, from https://www.trademap.org

Kantipur Daily. 2017. Retrieved March 4 , 2017, from www.ekantipur.com.np: http://kathmandupost.ekantipur.com /news/2017-12-02/barriers-make-life-difficult-for-gingerexporters.html

Khanal K. 2018. Factors Affecting and Marketing Chain of Ginger in Salyan. International Journal of Applied Sciences and Biotechnology.

Madan M. 2005. Production, Marketing, and Economics of Ginger. In P. Ravindran, \& K. N. Babu, Ginger The Genus Zingiber (p. 435). Washington D.C.: CRC Press.

Ministry of Industries. 2013. Cash incetive for export procedure, 2070 (In Nepali). Government of Nepal, Ministry of Industries.

MoAD. 2018. Statistical information on Neplese Agriculture. Kathmandu,NEPAL: Ministry of Agricultural Development.

MoC. 2016. Nepal Trade Integration Strategy, 2016. Kathmandu: Ministry of Commerce, Government of Nepal.

MoCS. 2010. Nepal Trade Integration Strategy (2010). Kathmandu: Ministry of Commerces and Supplies, Government of Nepal.

Plotto A. 2002. GINGER: Post-Production Managment for Improved Market Access. Food and Agriculture Organization of the United Nations (FAO), AGST.

Poudel R, Regmi P, Thapa R, GC Y, KC D. 2015. Socioeconomic aspects of ginger producers in the Western Hills of Nepal. Nepalese Journal of Agricultural Science, 48-59.

Republica Daily. 2018. Retrieved Janawary 28, 2018, from www.myrepublica.com: http://www.myrepublica.com/news /34895/? categoryId $=81$

Samarth. 2014. oppurtunities for Neplese ginger and Derivative Products in Japan, Dubai and Netharlands.

Sharma, B. 2009. Present status of ginge: Strategies for improving income and employment in Palpa, Pyuthan and Ilam . Kathmandu: GTZ/INCLUDE.

TEPC. 2018. Export Import Data Bank. Retrieved 04 02, 2018, from http://www.efourcore.com.np/tepcdatabank/

USAID. 2011. Value chain market analysis of the ginger sub sector in Nepal. Kathmandu.

Vasala P. 2012. Ginger. In K. Peter, Handbook of Herbs and Spices (Second edition) (pp. 319-335). Oxford: Woodhead Publishing Series in Food Science, Technology and Nutrition. 